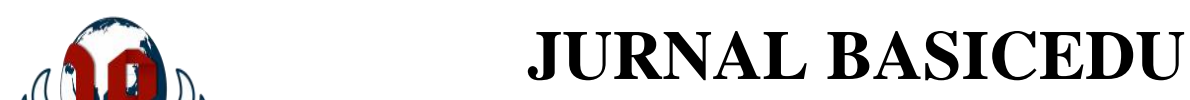

Volume 5 Nomor 4 Tahun 2021 Halaman 1717-1724

Research \& Learning in Elementary Education https://jbasic.org/index.php/basicedu

\title{
Peningkatan Keaktifan Belajar Melalui Model Discovery Learning Di Sekolah Dasar
}

\author{
Apri Dwi Prasetyo ${ }^{1 凶}$, Muhammad Abduh ${ }^{2}$ \\ Universitas Muhammadiyah Surakarta, Indonesia ${ }^{1,2}$ \\ E-mail: apridwi1923@ gmail.com ${ }^{1}$, ma123@ ums.ac.id $^{2}$
}

\begin{abstract}
Abstrak
Penelitian ini dilatar belakangi karena kurang aktifnya siswa dalam kegiatan pembelajaran. Hal ini terjadi karena guru masih dominan dalam menggunakan metode ceramah dan kurang dalam memanfaatkan media pembelajaran. Tujuan penelitian ini untuk meningkatkan keaktifan belajar siswa dalam proses pembelajaran di kelas. Penelitian ini menggunakan model discovery learning dengan metode penelitian tindakan kelas sebanyak dua siklus. Setiap siklus dilaksanakan dalam dua pertemuan dengan empat tahap kegiatan yaitu, perencanaan, tindakan, observasi, dan refleksi. Subjek penelitian adalah siswa kelas III SD Negeri 3 Pandean dengan jumlah 35 orang. Teknik pengumpulan data yang digunakan adalah observasi, dokumentasi, dan tes. Hasil penelitian pra siklus menunjukkan bahwa hasil rata-rata keaktifan siswa sebesar $41,53 \%$, sedangkan pada siklus I memperoleh persentase $60,91 \%$ dan meningkat sebesar $82,89 \%$ pada siklus II. Dengan demikian dapat disimpulkan bahwa penggunaan model discovery learning dapat meningkatkan keaktifan belajar siswa pada tema perkembangan teknologi.
\end{abstract}

Kata Kunci: keaktifan siswa, model discovery learning, pendidikan dasar.

\section{Abstract}

This research is based on the lack of student activeness in learning activities. This happens because the teacher is still dominant in using the lecture method and is lacking in utilizing learning media. The purpose of this study was to escalate student activeness in the learning process in the classroom using the discovery learning model. This study used a classroom action research method which was conducted in two cycles. Each cycle is held in two meetings with four stages of activity like planning, acting, observing, and reflecting. The research subjects were 35 students of SD Negeri 3 Pandean grade III. The data collection techniques used were observation, documentation, and tests. The results of pre-cycle research showed that the average result of student activeness was $41.53 \%$, while in the first cycle the percentage was $60.91 \%$ and increased by $82.89 \%$ in the second cycle. Thus it can be concluded that the use of discovery learning models can increase student learning activeness in the theme of technological developments.

Key words: student activeness, discovery learning model, basic education.

Copyright (c) 2021 Apri Dwi Prasetyo, Muhammad Abduh

Corresponding author :

Email : apridwi1923@gmail.com

DOI $\quad$ : https://doi.org/10.31004/basicedu.v5i4.991

ISSN 2580-3735 (Media Cetak)

ISSN 2580-1147 (Media Online) 
1718 Peningkatan Keaktifan Belajar Siswa Melalu Model Discovery Learning Di sekolah Dasar- Apri Dwi Prasetyo, Muhammad Abduh

DOI : https://doi.org/10.31004/basicedu.v5i4.991

\section{PENDAHULUAN}

Pendidikan menurut Undang-undang Sistem Pendidikan Nasional (Sisdiknas) No.20 tahun 2003 adalah usaha sadar dan terencana untuk mewujudkan suasana belajar dan proses pembelajaran agar siswa secara aktif mengembangkan potensi dirinya untuk memiliki kekuatan sipiritual keagamaan, pengendalian diri, kepribadian, kecerdasan, akhlak mulia, serta keterampilan yang diperlukan dirinya, masyarakat, bangsa dan negara. Belajar merupakan suatu proses yang ditandai dengan adanya perubahan pada diri seseorang. Perubahan hasil proses belajar dapat ditunjukkan dalam berbagai bentuk meliputi aspek afektif, kognitif dan psikomotor. Kegiatan pembelajaran memerlukan keaktifan belajar yakni dengan partisipasi kolaboratif antara guru dan siswa. Keaktifan belajar merupakan kegiatan atau kesibukan siswa dalam kegiatan belajar mengajar di sekolah maupun di luar sekolah yang menunjang keberhasilan siswa (Ulun, 2013: 12). Jadi keaktifan belajar adalah upaya siswa dalam mengembangkan potensi diri melalui serangkaian proses kegiatan belajar, baik pembelajaran secara tatap muka maupun pembelajaran secara daring untuk mencapai tujuan belajar.

Bentuk-bentuk keaktifan siswa dalam pembelajaran dapat dilihat dari keterlibatan siswa dalam proses pembelajaran seperti turut sertanya dalam mengerjakan tugas, terlibat dalam diskusi proses pemecahan masalah, bertanya kepada teman atau guru apabila tidak memahami materi, dan mampu mempresentasikan hasil laporan. Sedangkan faktor yang mempengaruhi keaktifan belajar menurut Gagne (Martinis, 2013: 84) diantaranya: memberikan dorongan atau menarik perhatian siswa, menjelaskan tujuan intruksional (kemampuan dasar kepada siswa), mengingatkan kompetensi belajar kepada siswa, memberikan stimulus (masalah, topik dan konsep yang akan dipelajari), memberi petunjuk kepada siswa cara mempelajarinya, memunculkan aktivitas, partisipasi siswa dalam kegiatan pembelajaran, memberi umpan balik (feed back), melakukan tes singkat diakhir pembelajaran, menyimpulkan setiap materi yang di sampaikan di akhir pembelajaran.

Indikator keaktifan belajar menurut (Sudjana, 2016: 61) dapat dilihat dari beberapa hal yaitu: (1) Ketika kegiatan belajar mengajar berlangsung siswa turut serta melaksanakan tugas belajarnya, (2) Siswa mau terlibat dalam pemecahan masalah dalam kegiatan pembelajaran, (3) Siswa mau bertanya kepada teman atau kepada guru apabila tidak memahami materi atau menemui kesulitan, (4) Siswa mau berusaha mencari informasi yang dapat diperlukan untuk pemecahan persoalan yang sedang dihadapinya, (5) Siswa melakukan diskusi kelompok sesuai dengan petunjuk guru, (6) Siswa mampu menilai kemampuan dirinya dan hasil-hasil yang diperolehnya, (7) Siswa belatih memecahkan soal atau masalah, dan (7) Siswa memiliki kesempatan menggunakan atau menerapkan apa yang telah diperolehnya dalam menyelesaikan tugas atau persoalan yang dihadapinya.

Berdasarkan hasil observasi permasalahan yang dijumpai di SD Negeri 3 Pandean yakni: (1) Kurang aktifnya siswa dalam kegiatan pembelajaran, (2) Siswa bosan dengan pembelajaran yang berlangsung (media pembelajaran yang kurang bervariatif), (3) Siswa kurang memberi respon terhadap pertanyaan yang diajukan guru, (4) Siswa belum memahami secara maksimal materi yang disampaikan, dan (5) Kurangnya penerapan model pembelajaran yang cocok untuk karakteristik siswa. Mengantisipasi masalah tersebut, dalam proses pembelajaran harus digunakan model pembelajaran yang sesuai agar hasil belajar siswa dapat meningkat. Stategi pembelajaran yang diharapkan peneliti adalah penggunaan model pembelajaran yang mampu membantu siswa menjadi aktif, kreatif, serta dengan mudah mempelajari konsep sehingga tujuan pembelajaran dapat tercapai. Untuk meningkatkan keaktifan dan hasil belajar siswa, salah satu model pembelajaran yang dapat diterapkan sesuai dengan karakteristik siswa adalah discovery learning.

Menurut (Hosnan, 2016: 282) pengertian discovery learning ialah model pengembangan cara belajar aktif dengan mendapatkan dan mengkaji sendiri, maka hasil yang didapatkan bisa terus di ingat. Dengan menggunakan metode belajar ini, siswa juga dapat belajar berpikir menganalisa dan memecahkan masalahnya. Selanjutnya menurut (Hamalik, 2015: 29) discovery learning merupakan suatu model untuk mengembangkan 
1719 Peningkatan Keaktifan Belajar Siswa Melalu Model Discovery Learning Di sekolah Dasar- Apri Dwi Prasetyo, Muhammad Abduh

DOI : https://doi.org/10.31004/basicedu.v5i4.991

cara belajar siswa aktif dengan menemukan dan menyelidiki maka hasil yang diperoleh akan tahan lama dalam ingatan tidak akan mudah dilupakan siswa. Model discovery learning merupakan penemuan konsep dengan serangkaian data atau informasi yang didapatkan lewat pengamatan maupun percobaan (Cahyo, 2013: 100). Dari berbagai pendapat diatas dapat disimpulkan bahwa karakteristik model pembelajaran discovery learning antara lain: (1) mendalami dan menyelesaikan masalah untuk membentuk, menggabungkan, dan mengumumkan pengetahuan, (2) berfokus kepada siswa, dan (3) aktivitas menggabungkan pengetahuan baru dan pengetahuan yang telah ada sebelumnya.

Dalam penerapan model discovery learning terdiri dari enam langkah utama : (1) Stimulation, memulai kegiatan proses mengajar belajar dengan mengajukan pertanyaan, anjuran membaca buku, dan aktivitas belajar lainnya yang mengarah pada persiapan peecahan masalah, (2) Problem statement (pernyataan/identifikasi masalah), yakni memberi kesempatan kepada siswa untuk mengidentifikasi sebanyak mungkin agenda-agenda masalah yang relevan dengan bahan pelajaran, kemudian salah satunya dipilih dan dirumuskan dalam bentuk hipotesis (jawaban sementara atas pertanyaan masalah), (3) Data collection (pengumpulan data), memberi kesempatan kepada para siswa untuk mengumpulkan informasi sebanyakbanyaknya yang relevan untuk membuktikan benar atau tidaknya hipotesis, (4) Data processing (pengolahan data), mengolah data dan informasi yang telah diperoleh para siswa melalui diskusi, observasi, dan sebagainya lalu ditafsirkan, (5) Verification (pembuktian), yakni melakukan pemeriksaan secara cermat untuk membuktikan benar atau tidaknya hipotesis yang ditetapkan tadi dihubungkan dengan hasil data processing, (6) Generalization (generalisasi), menarik sebuah simpulan yang dapat dijadikan prinsip umum dan berlaku untuk semua kejadian atau masalah yang sama, dengan memperhatikan hasil verifikasi (Syah, 2017: 243).

Beberapa penelitian menunjukkan peningkatan keaktifan belajar dengan menggunakan model pembelajaran discovery learning. Diantaranya oleh (Istikomah dkk, 2018) pada penelitian yang dilakukan pada siklus I keberhasilan siswa 86\% dan siklus II meningkat menjadi 95\% dengan model pembelajaran discovery learning. Sejalan pada penelitian yang tersebut, (Sispariyanto dkk, 2019) penerapan model pembelajaran discovery learning pada siswa kelas IV. Hasil penelitian menunjukkan peningkatan persentase keaktifan belajar siswa, pada siklus I siswa sangat aktif sebanyak 7 siswa (32\%), siswa aktif 8 siswa (36\%) dan siswa cukup aktif menjadi 7 siswa (32\%). Peningkatan terjadi pada siklus II dengan siswa sangat aktif sebanyak 17 siswa (77\%), siswa aktif menjadi 5 siswa (23\%).

Selanjutnya (Lubis, 2017) Peningkatan keaktifan belajar dimulai dari pertemuan 1 siklus I sebesar 64\% dan pada pertemuan 2 siklus I sebesar 67\%. Sedangkan peningkatan Keaktifan Belajar pada siklus II dimulai dari pertemuan 1 siklus II sebesar $71 \%$ dan pada pertemuan 2 siklus II sebesar $82 \%$.

Berdasarkan permasalahan observasi pada SD Negeri 3 Pandean, dapat diasumsikan bahwa pembelajaran yang dilakukan belum maksimal. Perlu adanya perbaikan pembelajaran yang tepat untuk meningkatkan keaktifan belajar siswa. Solusi untuk meningkatkan masalah tersebut yaitu dengan menggunakan model pembelajaran yang inovatif. Model pembelajaran discovery learning adalah model pembelajaran yang di dalam proses pembelajaran menggunakan masalah dalam mencapai tujuan penelitian yang akan dibahas oleh peneliti, maka disusun hipotesis tindakan pada penelitian ini adalah: (1) mendeskripsikan langkah-langkah sintaks penerapan model pembelajaran discovery learning untuk meningkatkan keaktifan belajar pada siswa kelas III SD Negeri 3 Pandean, (2) meningkatkan keaktifan belajar pada muatan pembelajaran tematik dengan menggunakan model discovery learning pada siswa kelas III SD Negeri 3 Pandean.

\section{METODE PENELITIAN}

Jenis penelitian yang digunakan pada penelitian ini adalah penelitian tindakan kelas. Menurut (Aqib, 2011: 3) penelitian tindakan kelas adalah penelitian yang dilakukan oleh guru di kelasnya sendiri melalui 
1720 Peningkatan Keaktifan Belajar Siswa Melalu Model Discovery Learning Di sekolah Dasar- Apri Dwi Prasetyo, Muhammad Abduh

DOI : https://doi.org/10.31004/basicedu.v5i4.991

refleksi diri dengan tujuan untuk memperbaiki kinerjanya sehingga hasil belajar siswa meningkat. Sedangkan menurut (Kusuma, 2011: 60) penelitian tindakan kelas adalah penelitian yang dilakukan ketika sekelompok orang (siswa) di identifikasi permasalahannya, kemudian peneliti (guru) menetapkan suatu tindakan untuk mengatasinya. Jadi dapat disimpulkan tujuan PTK untuk mengubah perilaku pengajaran guru, perilaku siswa di kelas, peningkatan atau perbaikan praktik pembelajaran, dan atau mengubah kerangka kerja melaksanakan pembelajaran kelas yang diajar oleh guru tersebut sehingga terjadi peningkatan layanan profesional guru dalam menangani proses pembelajaran.

Penelitian ini dilakukan secara kolaboratif dan partisipatif. Kolaboratif berarti peneliti bekerjasama dengan guru kelas, sedangkan partisipatif berarti peneliti dibantu teman sejawat (observer). Penelitian ini dimaksudkan untuk memberikan informasi bagaimana cara untuk meningkatkan keaktifan siswa pada materi tema perkembangan teknologi dengan metode discovery learning. Oleh sebab itu, penelitian ini difokuskan pada tindakan-tindakan sebagai usaha untuk meningkatkan keaktifan dan kompetensi kognitif siswa. Pelaksanaan penelitian ini dilakukan dengan beberapa siklus, serta dengan menggunakan model spiral sesuai dengan yang dikemukakan oleh Kurt Lewin dalam (Mulyatiningsih, 2014: 243) yang terdiri dari perencanaan, observasi \& tindakan serta refleksi. Prosedur pada setiap siklus saling berkesinambungan.

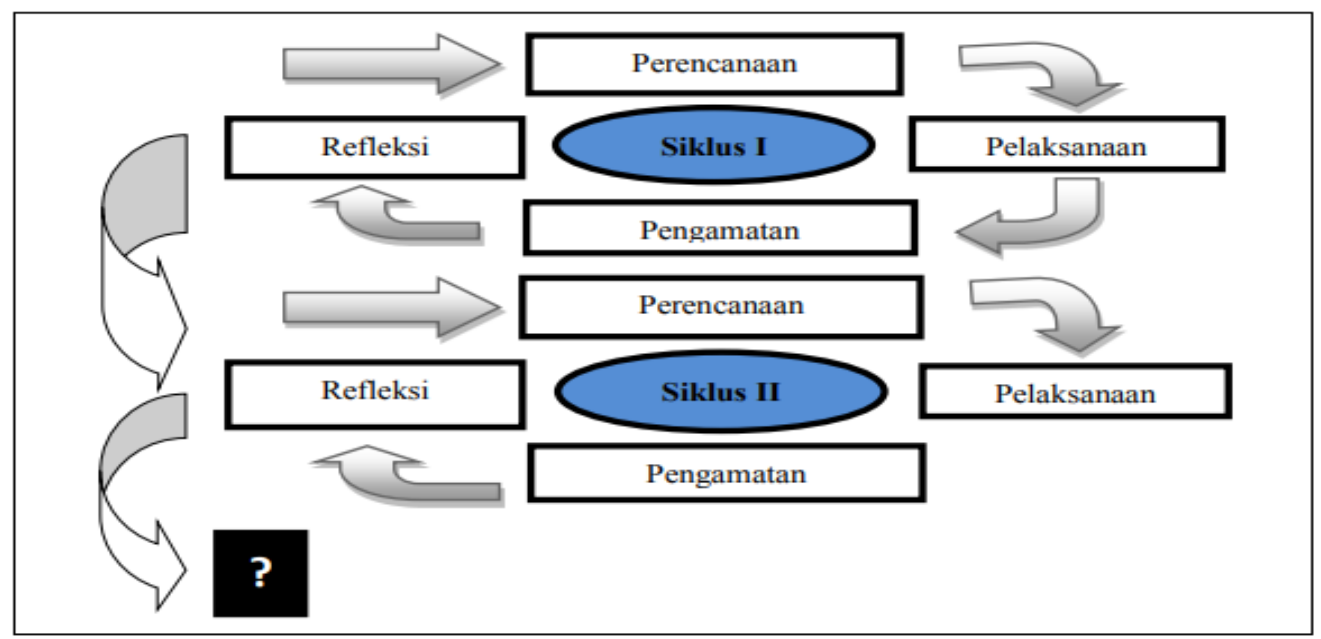

Gambar 1. Bagan Model Spiral oleh Kurt Lewin

Penelitian ini dilaksanakan di SD Negeri 3 Pandean, Kecamatan Ngemplak, Kabupaten Boyolali. Waktu penelitian ini dilaksanakan selama empat bulan terhitung dimulai sejak bulan Januari 2021 sampai April 2021. Subjek dalam penelitian merupakan siswa kelas III. Jumlah siswa kelas III berjumlah 35, dengan rincian 20 siswa laki-laki dan 15 siswa perempuan. Alasan dipilihnya kelas ini karena berdasarkan observasi dan wawancara memiliki keaktifan yang lebih rendah dibandingkan dengan kelas yang lainnya. Objek dalam penelitian ini adalah masalah rendahnya keaktifan dan hasil belajar kognitif siswa, kemudian dicarikan solusi untuk mengatasinya dengan menerapkan model pembelajaran discovery learning untuk meningkatkan keaktifan dan hasil belajar kognitif siswa.

Teknik pengumpulan data digunakan untuk mengumpulkan data sesuai tata cara penelitian sehingga diperoleh data yang dibutuhkan. Menurut (Riduwan, 2012: 51) teknik pengumpulan data merupakan langkah yang paling strategis dalam penelitian, karena tujuan utama dari penelitian adalah mengumpulkan data. Teknik pengumpulan data dalam penelitian ini menggunakan teknik observasi, wawancara, dokumentasi dan tes.

Teknik analisis data yang digunakan dalam penelitian ini adalah teknik analisis Miles (Sugiyono, 2018: 335) yang terdiri atas empat tahapan yang harus dilakukan di antaranya perencanaan, tindakan, observasi, dan 
1721 Peningkatan Keaktifan Belajar Siswa Melalu Model Discovery Learning Di sekolah Dasar- Apri Dwi Prasetyo, Muhammad Abduh

DOI : https://doi.org/10.31004/basicedu.v5i4.991

refleksi. Dalam penelitian ini analisis data yang digunakan adalah data kuantitatif dan data kualitatif. Data kuantitatif dianalisi dengan deskriptif komparatif yaitu membandingkan hasil hitung dan statistik deskriptif, misalnya hasil persentase pada satu siklus dengan siklus berikutnya. Sedangkan data kualitatif dianalisis dengan analisis kritis, yaitu mengidentifikasi kelemahan dan kelebihan keaktifan kinerja siswa selama proses penerapan tindakan.

Sistem penilaian keaktifan belajar siswa yang digunakan pada rubrik penilaian ini ialah setiap 1 item indikator mendapat skor maksimal 4 poin. Adapun skor maksimal total rubrik ialah 56 poin per siklus. Indikator keaktifan belajar yang diamati antara lain: (1) memperhatikan penjelasan guru, (2) mengajukan pertanyaan, (3) merespon pertanyaan, (4) berdiskusi dalam kelompok, (5) mencatat rangkuman materi pelajaran, (6) menyampaikan ide/gagasan, dan (7) mempresentasikan hasil kerja kelompok.

Tabel 1. Indikator Capaian Penelitian Keaktifan Siswa

\begin{tabular}{|l|l|}
\hline Capaian & Kriteria \\
\hline $75 \%-100 \%$ & Tinggi \\
\hline $51 \%-74 \%$ & Sedang \\
\hline $25 \%-50 \%$ & Rendah \\
\hline $0 \%-24 \%$ & Sangat Rendah \\
\hline
\end{tabular}

Sumber: (Arikunto, 2017: 130)

Indikator keberhasilan di dalam pelaksanaan penelitian ini dipandang berhasil apabila sudah memenuhi keberhasilan tindakan yaitu keaktifan belajar siswa melalui penerapan model discovery learning tema perkembangan teknologi kelas III di SD Negeri 3 Pandean dengan persentase mencapai $80 \%$ (berkriteria tinggi) dari 35 siswa. Indikator proses pembelajaran dalam penelitian ini akan dilihat dari persentase keberhasilan tindakan yang didasarkan pada data skor yang diperoleh dari hasil observasi siswa. Untuk menghitung observasi aktivitas siswa, peneliti menggunakan rumus persentase sebagai berikut :

$$
\text { Presentase keberhasilan tindakan }=\frac{\sum \text { Jumlah skor yang diperoleh }}{\sum \text { Skor maksimal }} \times 100 \%
$$

Sumber: (Djamarah, 2016: 67)

\section{HASIL PENELITIAN DAN PEMBAHASAN}

Berdasarkan pembelajaran yang telah dilakukan dari awal siklus I hingga pada siklus II, keaktifan belajar siswa mengalami peningkatan yang signifikan. Hasil penelitian tindakan kelas diperoleh kesimpulan bahwa tindakan belajar dengan model discovery learning dapat meningkatkan keaktifan belajar siswa. Selanjutnya tabel di bawah ini merupakan hasil perbandingan penelitian keaktifan belajar siswa tema perkembangan teknologi menggunakan model discovery learning.

Tabel 2. Perbandingan Keaktifan Belajar Siswa

\begin{tabular}{|l|l|c|c|c|c|c|c|}
\hline \multirow{2}{*}{ No. } & Kategori Keaktifan & \multicolumn{2}{|c|}{ Pra Siklus } & \multicolumn{2}{c|}{ Siklus I } & \multicolumn{2}{c|}{ Siklus II } \\
\cline { 3 - 8 } & Belajar Siswa & F & \% & F & \% & F & \% \\
\hline 1. & Tinggi & 4 & $11,42 \%$ & 10 & $28,57 \%$ & 21 & $60,00 \%$ \\
\hline 2. & Sedang & 7 & $20,00 \%$ & 17 & $48,57 \%$ & 13 & $37,14 \%$ \\
\hline 3. & Rendah & 15 & $42,85 \%$ & 8 & $22,58 \%$ & 1 & $2,85 \%$ \\
\hline 4. & Sangat Rendah & 9 & $25,71 \%$ & 0 & $0 \%$ & 0 & $0 \%$ \\
\hline
\end{tabular}


1722 Peningkatan Keaktifan Belajar Siswa Melalu Model Discovery Learning Di sekolah Dasar- Apri Dwi Prasetyo, Muhammad Abduh

DOI : https://doi.org/10.31004/basicedu.v5i4.991

Pada tabel 1 diatas diketahui bahwa perbandingan nilai keaktifan belajar siswa. Pada pra siklus diketahui dari keseluruhan 35 siswa yang mendapat kategori keaktifan "Tinggi" sebanyak 4 siswa dengan persentase 11,42\%, kemudian pada hasil keaktifan "Sedang" sebanyak 7 siswa dengan persentase $20 \%$. Selanjutnya pada kategori keaktifan "Rendah" terdapat 15 siswa dengan persentase $42,85 \%$ dan pada keaktifan"Sangat Rendah" terdapat 9 siswa dengan persentase 25,71\%. Setelah dilaksanakan siklus I pada kategori keaktifan "Tinggi" sebanyak 10 siswa dengan persentase $28,57 \%$, kemudian pada hasil keaktifan "Sedang" sebanyak 17 siswa dengan persentase 48,57\%. Selanjutnya pada kategori keaktifan "Rendah" terdapat 8 siswa dengan persentase $22,58 \%$ dan pada keaktifan "Sangat Rendah" terdapat 0 siswa dengan persentase $0 \%$. Setelah melaksanakan siklus II diketahui hasil keaktifan belajar siswa mendapat kategori "Tinggi" sebanyak 21 siswa dengan persentase 60\% kemudian pada hasil keaktifan "Sedang" sebanyak 13 siswa dengan persentase $37,14 \%$. Selanjutnya pada kategori keaktifan "Rendah" terdapat 1 siswa dengan persentase $2,85 \%$ dan pada keaktifan "Sangat Rendah" terdapat 0 siswa dengan persentase $0 \%$.

Tabel 3. Skor Keaktifan Belajar Pada Pra Siklus, Siklus I, dan Siklus II

\begin{tabular}{|c|l|c|c|c|}
\hline No. & & Pra Siklus & Siklus I & Siklus II \\
\hline 1. & Skor Terendah & 16 & 28 & 34 \\
\hline 2. & Skor Tertinggi & 46 & 51 & 55 \\
\hline 3. & Rata-Rata & $41,53 \%$ & $60,91 \%$ & $82,89 \%$ \\
\hline 4. & Kategori & Keaktifan Rendah & Keaktifan Sedang & Keaktifan Tinggi \\
\hline
\end{tabular}

Berdasarkan tabel diatas dapat diketahui pada tindakan pra siklus memperoleh persentase rata-rata keaktifan siswa sebesar $41,53 \%$ dengan kategori keaktifan siswa rendah, kemudian meningkat pada siklus I memperoleh rata-rata 60,91\% dengan kategori keaktifan siswa sedang, namun hasil yang diperoleh pada siklus I belum sesuai dengan indikator pencapaian yang telah ditetapkan karena masih mengalami beberapa kendala yakni masih ada siswa yang tidak memperhatikan guru dalam menjelaskan materi, kurangnya komunikasi siswa dalam diskusi kelompok tugas yang diberikan oleh guru, dan masih banyak siswa yang tampak ragu dalam menjawab pertanyaan dan mengajukan pertanyaan. Sehingga untuk meningkatkan keaktifan belajar siswa agar mencapai kriteria keberhasilan dilakukan perbaikan pada siklus II.

Setelah dilakukan perbaikan tindakan pada siklus II peningkatan keaktifan dari $60,91 \%$ pada siklus I meningkat menjadi $82,89 \%$ pada siklus II dengan kategori keaktifan belajar siswa tinggi. Keaktifan siswa pada siklus II lebih baik dibandingkan siklus I, hal ini ditunjukkan dengan semakin banyaknya siswa memperhatikan materi yang disampaikan guru karena pembelajaran yang disajikan dengan model pembelajaran discovery learning dapat meningkatkan semangat belajar siswa, kebermaknaan proses belajar ini di dukung dengan perangkat pembelajaran berbasis TPACK sehingga media yang disajikan lebih bervariatif. Selanjutnya dalam pengerjaan LKPD siswa terlihat antusias dalam diskusi kelompok dimana siswa mampu mengemukakan pendapatnya terhadap permasalahan yang ada dalam materi ajar, dan banyak siswa yang aktif dalam bertanya ataupun menjawab pertanyaan yang diberikan, kemudian siswa terlihat percaya diri dalam mempresentasikan hasil pekerjaan dalam masing-masing kelompok secara bergantian.

Pada penelitian ini juga di dukung dengan penelitian lain, salah satunya penelitian yang dilakukan oleh (Rahayu dkk, 2019) penerapan model discovery learning untuk meningkatkan keaktifan dan hasil belajar tematik di kelas V. Persentase keaktifan siswa 54,55\% di siklus I dan meningkat kembali menjadi 81,82\% di siklus II. Peningkatan tersebut terjadi karena guru telah menerapkan model pembelajaran sesuai sintaknya dan dapat memancing siswa untuk terlibat aktif dalam pembelajaran sehingga siswa dapat memahami materi secara leluasa. Selanjutnya penelitian dari (Prayitno dkk, 2017) mengungkapkan hasil penelitian tentang peningkatan keaktifan siswa dengan model discovery learning pada konsep klasifikasi makhluk hidup. Hasil penelitian menunjukkan bahwa model pembelajaran discovery learning dapat meningkatkan keaktifan belajar 
1723 Peningkatan Keaktifan Belajar Siswa Melalu Model Discovery Learning Di sekolah Dasar- Apri Dwi Prasetyo, Muhammad Abduh

DOI : https://doi.org/10.31004/basicedu.v5i4.991

siswa dalam proses pembelajaran. Keaktifan siswa pada siklus I sebesar 58,92\% dengan kategori sedang meningkat menjadi $85,93 \%$ pada siklus II dengan kategori tinggi.



Gambar 1. Grafik Peningkatan keaktifan Belajar Siswa

Data hasil penelitian menunjukkan bahwa adanya peningkatan keaktifan belajar siswa dari pra siklus, siklus I hingga siklus II. Hal ini disebabkan karena sebagian besar siswa mampu memenuhi kriteria indikator keaktifan belajar dan menyelesaikan tugas dengan sungguh-sungguh. Hal ini menunjukkan bahwa dengan menerapkan model pembelajaran discovery learning dapat meningkatkan keaktifan belajar pada siswa kelas III SD Negeri 3 Pandean Tahun Ajaran 2020/2021. Pembelajaran dengan menggunakan discovery learning dapat memunculkan interaksi kolaborasi antara siswa dengan siswa maupun siswa dengan guru. Interaksi tersebut dapat mendukung kelancaran proses pembelajaran dimana siswa menunjukkan antusias yang tinggi selama proses pembelajaran berlangsung. Guru hanya memfasilitasi agar siswa aktif melakukan berbagai aktivitas dalam proses pembelajaran. Keaktifan ini membuat siswa lebih antusias dalam memperhatikan penjelasan guru, memunculkan keberanian siswa untuk bertanya, merespon pertanyaan, berdiskusi dalam kelompok, mencatat rangkuman materi pelajaran, menyampaikan ide atau gagasan, dan mempresentasikan hasil kerja kelompok.

\section{KESIMPULAN}

Berdasarkan penilitian yang dilakukan dapat disimpulkan bahwa: (1) Model pembelajaran discovery learning dengan sintaks pada tahap awal siswa diberi stimulasi atau pemberian rangsangan, kemuadian siswa mengidentifikasi masalah, mengupulkan data, setelah pengumpulan data siswa mengolah, kemudian siswa melakukan pembuktian terhadap data yang di peroleh, dan pada tahap terakhir siswa menarikan kesimpulan. Langkah-langkah model pembelajaran discovery learning tersebut dapat meningkatkan keaktifan belajar siswa pada muatan pembelejaran tematik materi perkembangan teknologi kelas III SD Negeri 3 Pandean. (2) Hasil penelitian menunjukkan bahwa ada peningkatan hasil rata-rata keaktifan belajar siswa secara klasikal yang dilakukan dari tindakan pra siklus ke siklus I dan ke siklus II. Persentase rata-rata keaktifan belajar siswa pada pra siklus sebesar 41,53\% dengan kategori "rendah". Pada siklus I persentase rata-rata keaktifan belajar siswa meningkat sebesar 60,91\% berada pada kategori keaktifan siswa "sedang". Sedangkan pada siklus II persentase rata-rata keaktifan belajar siswa meningkat sebesar $82,89 \%$ berada pada kategori keaktifan siswa "tinggi". Dari hasil yang diperoleh pada tindakan siklus II dapat dikatakan telah memenuhi kriteria keberhasilan yang telah ditetapkan. Dengan demikian dapat disimpulkan bahwa model pembelajaran discovery learning dapat meningkatkan keaktifan belajar pada siswa kelas III tema perkembangan teknologi di SD Negeri 3 Pandean Tahun Pelajaran 2020/2021. 
1724 Peningkatan Keaktifan Belajar Siswa Melalu Model Discovery Learning Di sekolah Dasar- Apri Dwi Prasetyo, Muhammad Abduh

DOI : https://doi.org/10.31004/basicedu.v5i4.991

\section{UCAPAN TERIMAKASIH}

Penulis dalam menyusun penelitian ini mengucapkan puji syukur kepada Allah SWT atas segala limpahan rahmat dan hidayah dalam menyusun penelitian ini. Peneliti mengucapkan terima kasih kepada kepala sekolah SD Negeri 3 Pandean yang telah memberikan izin untuk melakukan penelitian, serta dosen pembimbing PPG FKIP UMS, dan guru pamong PPG FKIP UMS yang telah memberikan bimbingan dan arahannya. Semoga penelitian yang disusun ini dapat bermanfaat bagi semua pihak.

\section{DAFTAR PUSTAKA}

Aqib, Zainal, dkk, 2011. Penelitian Tindakan Kelas untuk Guru SD, SLB, dan TK. Bandung: Yrama Widya. Arikunto, S., 2017. Pengembangan Instrumen Penelitian dan Penilaian Program.Yogyakarta: Pustaka Pelajar. Cahyo, A., 2013. Panduan Aplikasi Teori Belajar. Jakarta. PT. Diva Press.

Djamarah, 2016. Strategi Belajar Mengajar. Jakarta : Rineka Cipta., Yogyakarta: UNY.

Hamalik, O., 2015. Kurikulum dan Pembelajaran. Jakarta: Bumi Aksara.

Hosnan, 2016. Pendekatan Saintifik dan Kontekstual dalam Pembelajaran Abad 21. Bogor: Ghalia Indonesia.

Kusuma, W., 2011. Penelitian Tindakan Kelas. Jakarta: PT Indeks.

Lubis, W.A., 2017. Peningkatan Keaktifan Belajar dan Hasil Belajar Siswa Dalam Pembelajaran IPA dengan Metode Kerja Kelompok Untuk Kelas III SDN Sepatan Kabupaten Tulungagung. Other thesis, Univ. Muhammadiyah Malang.

Martinis, Y., 2013. Strategi dan Metode dalam Model Pembelajaran. Jakarta:Referensi (GP Press Group).

Mulyatiningsih, E., 2014. Metode Penelitian Terapan Bidang Pendidikan. Bandung: Alfabeta.

Nurul Istikomah, S.C.R.A.T.A.H., 2018. Penerapan Model Discovery Learning Pada Pembelajaran Ips Untuk Meningkatkan Keaktifan Dan Hasil Belajar Kognitif Siswa Sekolah Dasar. J. Didakt. Dwija Indria 6, $130-139$.

Prayitno, B.W \& W.Dian, R.., 2017. Publised Desember 2017 3, 136-143.

Rahayu, Iin Puji., \& Hardini, A.T.., 2019. Penerapan Model Discovery Learning Untuk Meningkatkan Aktivitas Dan Hasil Belajar Siswa. Diklabio J. Pendidik. dan Pembelajaran Biol. 3, 193-200. https://doi.org/10.33369/diklabio.2.1.15-20

Riduwan, 2012. Metode \& Teknik Menyusun Proposal Penelitian. Bandung: Alfabeta.

Sisdiknas, 2003. Undang-Undang Republik Indonesia Nomor 20 Tahun 2003 Teundang-Undang Republik Indonesia Nomor 20 Tahun 2003 Tentang Sistem Pendidikan Nasional, Pub. L. No. Bab Ii, Pasal 3, 1 (2003). 1-21.

Sispariyanto, E., Relmasira, S.C., Hardini, A.T.A., 2019. Upaya Meningkatkan Keaktifan Dan Hasil Belajar Ipa Melalui Model Discovery Learning Di Kelas Iv Sd. J. Cakrawala Pendas 5, 87-93. https://doi.org/10.31949/jcp.v5i2.1333

Sudjana, N., 2016. Penilaian Hasil Proses Belajar Mengajar. Bandung:Rosdikarya.

Sugiyono, 2018. Metode Penelitian Pendidikan Pendekatan Kuantitatif, Kualitatif, dan R\&D. Bandung: Alfabeta.

Syah, M., 2017. Psikologi Pendidikan dengan Pendekatan Baru. Bandung: PT. Remaja Rosdakarya.

Ulun, 2013. Pembelajaran Aktif: Teori Dan Asesmen. Bandung: Remaja Rosdakarya. 